
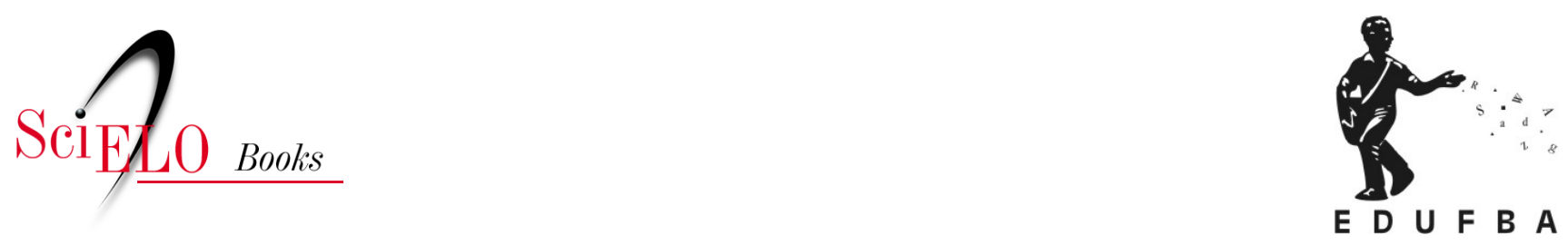

\title{
Reflexões \\ Educação, a cultura da obsolescência e gambiarras
}

\author{
Nelson De Luca Pretto
}

PRETTO, N.D.L. Educação, a cultura da obsolescência e gambiarras. In: Educações, culturas e hackers: escritos e reflexões [online]. Salvador: EDUFBA, 2017, pp. 145-146. ISBN: 978-85-232-2019-8.

https://doi.org/10.7476/9788523220198.0033.

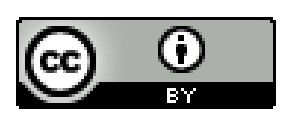

All the contents of this work, except where otherwise noted, is licensed under a Creative Commons Attribution $\underline{4.0 \text { International license. }}$

Todo o conteúdo deste trabalho, exceto quando houver ressalva, é publicado sob a licença Creative Commons Atribição 4.0. 
zer seus elementos mais criativos, estaremos caminhando para formação de cidadãos comprometidos com o futuro do planeta.

\section{Educação, a cultura da obsolescência e gambiarras}

Um dia desses visitava um querido amigo e colega, Fritz Gutman, que, para mim, é um físico, gênio das traquitanas. Ao lá chegar, reencontrei sua oficina, no fundo da casa, cheia de tralhas. Literalmente tralhas: resto de rádios, fios, pedaços de cadeiras, latas, aparelhos eletrônicos e elétricos, espalhados por paredes e por bancadas. Dali saíram suportes para janelas, sistemas automatizados de fechar portas, bancos para jardins, cenários para teatro - coisa que ele faz muito. Conversa vai, conversa vem, lembro meus primeiros cursos a distância, pelo Instituto Monitor, que me enviava os manuais e, de tempo em tempo, algumas ferramentas para as atividades práticas, como a construção de um rádio de galena (aposto que a quase totalidade dos leitores nem sabe o que é isso! tem na Wikipedia, veja lá!). Pois, sou um encantado com as gambiarras. Já escrevi sobre isso no jornal A Tarde, de 18 de novembro de 2011, comentando o livro de Matthew Crawford, de 2009, que tratava sobre essa a importância de se trabalhar com as mãos.

Pois na conversa com Fritz, relembrávamos o nosso início no Instituto de Física da UFBA, quando lá existia uma oficina mecânica, outra elétrica e até mesmo uma de vidros. Todas super bem equipadas e com 
profissionais do quadro efetivo da Universidade. Lá consertávamos tudo. Nada ia para o lixo já no primeiro defeitinho!

Durante o tempo em que estive na direção da Faculdade de Educação (2000-2008), fiquei conhecido como badameiro, o que sou até hoje, com muito orgulho. Isso porque não deixava nada ir embora, sem antes tentar dar um jeitinho e pôr de novo o objeto quebrado em funcionamento, ou mesmo, dar a ele uma nova funcionalidade. Não temos mais nada disso. Em nome do tal Patrimônio, não podemos reutilizar nada. Ao menor defeito, vemos sair da nossa unidade, cadeiras, televisores, monitores, armários, um sem número de objetos que terminam mofando nos setores administrativos para os nem tão anuais leilões, onde são todos arrematados, já sem funcionalidade, por bagatela.

Fora o desperdício, constatamos que, cada vez menos, exercitamos a habilidade do fazer. Tudo é comprado pronto e só o que vale é o mais novo, mais moderno, mesmo que isso seja uma simples modificação estética, às vezes, até desnecessária. Em nossas escolas, essas atividades estão totalmente afastadas do cotidiano de professores e alunos e, o pior, já são até mesmo rejeitadas.

Quando vemos crescer a tendência da chamada escola de turno integral e, ao mesmo tempo, a insistência de se trabalhar nesse turno ampliado, com reforço em matemática e português, nada melhor do que voltar a pensar na implantação de laboratórios hackers, fablabs ou similares e, com isso, termos um grande programa educacional com a implantação de "oficinas de gambiarras" nas escolas, para fazer a meninada pôr a mão na massa e soltar a imaginação com criatividade.

Isso vale para todos os cantos do país e, muito mais, para uma Bahia que tem Carlinhos Brown, Peu Meurray, Bira Reis e tantos outros criadores genais. 